\title{
Transpired solar collectors for ventilation air heating
}

1 Richard Hall MEng, AlEMA EngD Researcher, Steel Construction Institute, Surrey EngD in Environmental Technology, University of Surrey, Guildford, UK

3 Raymond Ogden DiplArch, PhD Professor, Oxford Institute for Sustainable Development, Oxford Brookes University, Oxford, UK
2 Xiaoxin Wang MSc, PhD

Research Fellow, Oxford Institute for Sustainable Development, Oxford Brookes University, Oxford, UK

4 Lucia Elghali MSc, EngD, AlEMA

Programme Director, Surrey EngD in Environmental Technology, University of Surrey, Guildford, UK
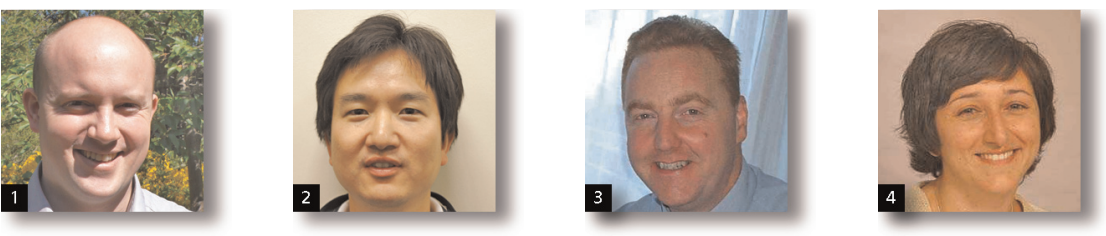

Transpired solar collectors (TSCs) improve the environmental performance of buildings by preheating incoming ventilation air using solar energy, substituting the need to use fossil fuels. TSCs have been used successfully in the USA and Canada over the past 20 years and have been shown to achieve economic payback of between 2 and 10 years. The economic performance is achieved through a combination of high thermal efficiency and the low cost of the solar collector, which is in the form of a single perforated steel sheet. In 2006, the first installation of a TSC in the UK was on a single-storey industrial building in County Durham and during its first year of operation, the TSC provided around $20 \%$ of the building's heating demand. This paper presents a review of the research into TSC technology, examining its thermal performance, the different construction types, annual energy performance, and international experiences. The evidence from the UK-based research performance investigations suggest that the success of TSCs in the USA and Canada could be replicated in the UK.

\section{Notation}

$A \quad$ area of the perforated absorber $\left(\mathrm{m}^{2}\right)$

$C_{\mathrm{p}} \quad$ specific heat of air $(\mathrm{J} / \mathrm{kg} . \mathrm{K})$

$G_{\mathrm{T}} \quad$ tilted solar irradiance $\left(\mathrm{W} / \mathrm{m}^{2}\right)$

$h_{\mathrm{rad}}$ linearised radiation heat transfer coefficient $\left(\mathrm{W} / \mathrm{m}^{2} . \mathrm{K}\right)$

$\dot{m} \quad$ mass flow rate $(\mathrm{kg} / \mathrm{s})$

$n_{\mathrm{i}} \quad$ instantaneous thermal efficiency

$T_{\mathrm{amb}}$ ambient air temperature (K)

$T_{\text {col }}$ perforated absorber temperature (K)

$T_{\text {out }}$ outlet air temperature (K)

$v \quad$ suction-face velocity $(\mathrm{m} / \mathrm{s})$

$\alpha \quad$ solar absorbance

$\varepsilon_{\mathrm{HX}}$ heat exchange effectiveness

$\rho_{\text {air }} \quad$ density of air $\left(\mathrm{kg} / \mathrm{m}^{3}\right)$

\section{Introduction}

In Europe, the operational energy use of buildings is around $40 \%$ of total energy consumption. In 2002, the European Union (EU) adopted the energy performance of buildings directive (EPBD), which aims to reduce the EU's energy dependency and reduce emissions of greenhouse gases by reducing the energy consumption of buildings (Ekins and Lees, 2008; EU, 2010). In the UK, operational energy use of buildings is estimated to be $39 \%$ of total energy consumption, with roughly $50 \%$ of the energy used in buildings due to the provision of heating, ventilation and air conditioning (HVAC) services (Pérez-Lombard et al., 2008).

One method of providing the heating component of HVAC services that both reduces energy dependency and results in lower greenhouse gas emissions is through the use of solar thermal systems, which convert solar radiation into thermal energy (Kalogirou, 2004). This paper describes a solar thermal system known as a transpired solar collector (TSC), which uses an unglazed perforated absorber as the solar-collecting component (Figure 1). TSCs can be used to preheat the ventilation air supply to buildings using solar radiation as its energy source.

\section{Transpired solar collectors}

TSCs were invented in the mid-1980s by John Hollick and Rolf Peter as a method of using solar radiation to preheat ventilation 


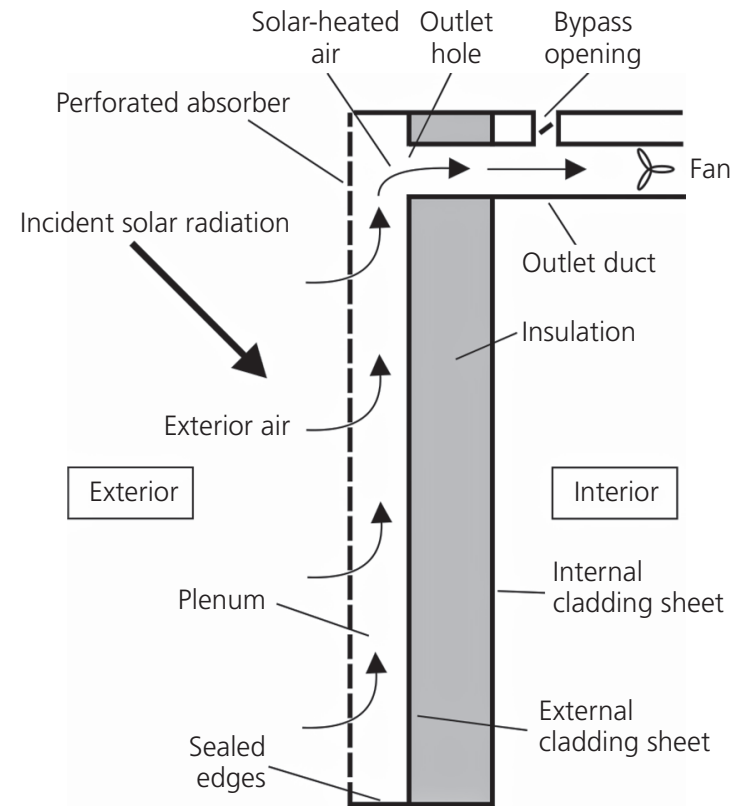

Figure 1. Schematic illustration of a transpired solar collector

air for buildings (Hollick, 1994; Kutscher, 1996). Since the first commercial installation of a TSC on the Ontario (Canada) Ford Motor Company assembly plant in 1990 (CEI, 2009a), over 1000 TSCs have been installed in more than 30 countries (CEI, 2009b). The first TSC system in the UK was installed in 2006 on the south wall of a single-storey industrial building (CA Group, 2009) and since then a number of TSCs have been installed and are now operating around the UK (see Table 1).

TSCs are constructed by fixing a solar absorbing perforated metallic sheet to the envelope of a building. This creates an air gap between the perforated sheet and the building envelope (plenum). Using a fan, exterior air is drawn into the plenum through thousands of evenly spaced perforations that cover the surface of the absorber. As the air passes over the front surface of the perforated sheet, heat is transferred by convection from the sheet to the air (Kutscher et al., 1993). The solar heated air is then drawn out of the plenum through the outlet hole, where it can be ducted towards its application (see Figure 1). When solar-heated air is not required, TSCs have a bypass opening so that the ventilation air stream can circumvent the perforated absorber (Kutscher, 1996). To direct the air to flow through the perforations, the plenum is sealed around all the edges. For large TSCs, the perforated absorber is usually profiled for structural rigidity.

Early on in their development, TSCs were shown to be competitive in many applications (Christensen et al., 1990); they combine instantaneous thermal efficiencies of over $70 \%$ (Brunger et al., 1999) with low capital investment costs. These two factors create the potential of simple economic payback of less than 2 years for large installations (Brewster, 2010; CEI, 2009a).

\section{Basic TSC energy balance equation}

The instantaneous thermal efficiency $\left(n_{\mathrm{i}}\right)$ of a TSC can be described using the standard flat-plate solar collector efficiency equation (Duffie and Beckman, 2006: p. 292), which is the energy transferred to the outlet air stream divided by the total solar radiation incident on the perforated absorber

1. $n_{\mathrm{i}}=\frac{\dot{m} C_{\mathrm{p}}\left(T_{\mathrm{out}}-T_{\mathrm{amb}}\right)}{A G_{\mathrm{T}}}$

where $C_{\mathrm{p}}$ is the specific heat of ambient air (ambient air is the term used in the solar thermal literature for exterior air (ASHRAE, 2010)), $A$ is the projected area of the perforated absorber, $\dot{m}$ is the mass flow rate though the perforated absorber, $T_{\text {out }}$ is the air leaving the perforated absorber, $G_{\mathrm{T}}$ is the total solar irradiance incident on the perforated absorber and $T_{\text {amb }}$ is the exterior air temperature. Equation 1 can be rearranged to find the temperature of the air leaving the TSC (Duffie and Beckman, 2006: pp. 278-289).

Similar to flat-plate solar collectors, the instantaneous thermal efficiency required by Equation 1 to find $T_{\text {out }}$ can be determined by performing an energy balance of the perforated absorber

\begin{tabular}{llcc}
\hline Project & Location & TSC area: $\mathrm{m}^{2}$ & Predicted energy savings: $\mathrm{kWh} / \mathrm{year}$ \\
\hline Jaguar/Land Rover & Leamington Spa & 268 & 80530 \\
Beaconsfield Services & Beaconsfield & 255 & 99235 \\
Premier Park & Winsford, Cheshire & 580 & 130000 \\
Sainsbury's Distribution & Pineham & 947 & 256093 \\
CA Group Rollforming Mill & Evenwood & 1211 & 299000 \\
International Paints & Felling, Gateshead & 100 & 31169 \\
Royal Mail & Swan Valley & 800 & 233396
\end{tabular}

Table 1. UK commercial installations of TSCs (Brewster, 2010; CA Group, 2010) 


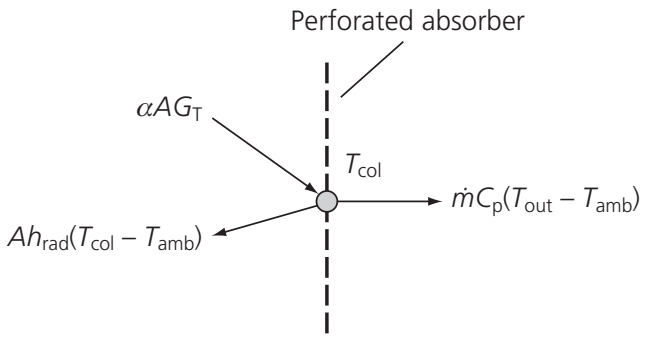

Figure 2. Simple energy balance on the perforated absorber

(Duffie and Beckman, 2006: p. 239). This energy balance is illustrated in Figure 2 and shown mathematically as

2. $\dot{m} C_{\mathrm{p}}\left(T_{\text {out }}-T_{\mathrm{amb}}\right)=\alpha A G_{\mathrm{T}}-A h_{\mathrm{rad}}\left(T_{\mathrm{col}}-T_{\mathrm{amb}}\right)$

where $\alpha$ is the absorptance of the perforated absorber (Duffie and Beckman, 2006: pp. 174-177), $T_{\text {col }}$ is the temperature of the perforated absorber and $h_{\mathrm{rad}}$ is the linearised radiation heat transfer coefficient (linearising the radiation heat transfer coefficient is an effective means of converting the temperature to the power of 4 as described by the Stefan-Boltzmann law to a linear formula over a narrow temperature range). Equation 2 assumes that the TSC is large and wind heat loss can be considered negligible (Gawlik and Kutscher, 2002).

Given that the energy transferred to the outlet air stream is a function of the design of the perforated absorber, a heat exchange effectiveness (HEE) ratio $\left(\varepsilon_{\mathrm{HX}}\right)$ is used to describe the relationship between the actual temperature rise against the maximum possible temperature rise

3. $\varepsilon_{\mathrm{HX}}=\frac{\left(T_{\mathrm{out}}-T_{\mathrm{amb}}\right)}{\left(T_{\mathrm{col}}-T_{\mathrm{amb}}\right)}$

where the HEE is determined experimentally (Brunger et al., 1999: p. 109). By rearranging Equation 3 for $T_{\text {out }}$ and substituting into Equation 2, Equation 2 is transformed into

4. $m C_{\mathrm{p}} \varepsilon_{\mathrm{HX}}\left(T_{\mathrm{col}}-T_{\mathrm{amb}}\right)=\alpha A G_{\mathrm{T}}-A h_{\mathrm{rad}}\left(T_{\mathrm{col}}-T_{\mathrm{amb}}\right)$

Equation 4 can then be rearranged for $A G_{\mathrm{T}}$ and substituted into Equation 1 to relate the characteristics of the perforated absorber and the mass flow rate to the instantaneous thermal efficiency. To simplify the result of substituting Equation 4 into Equation 1, the mass flow rate is expressed in terms of the suction-face velocity $v$, which is defined as the velocity of air if it were to travel though whole surface area of the absorber

5. $v=\frac{\dot{m}}{A \rho_{\text {air }}}$ where $\rho_{\text {air }}$ is the density of ambient air. Once these steps have been followed, the following equation for instantaneous thermal efficiency is obtained (Brunger et al., 1999: p. 102; Carpenter et al., 1999; Kutscher et al., 1991)

6.

$$
n_{\mathrm{i}}=\frac{\alpha}{\left[1+\left(h_{\mathrm{rad}} / \varepsilon_{\mathrm{HX}} \rho_{\text {air }} C_{\mathrm{p}} v\right)\right]}
$$

Equation 6 shows that the efficiency of the TSC is proportional to its absorptivity. Broadly speaking, absorptivity is higher in darker colours and as TSCs tend to cover large sections of the building's south wall, careful design is required to balance aesthetics and thermal efficiency. Depending upon the application, colours such as blue, red, green and grey can be considered as having good solar absorptance characteristics (Corus Colors, 2010).

Figure 3 shows Equation 6 modelled for suction-face velocities between 0.001 and $0.06 \mathrm{~m} / \mathrm{s}$, and demonstrates that TSCs are able to achieve instantaneous efficiency of over $70 \%$ when operating at suction-face velocities above $0.02 \mathrm{~m} / \mathrm{s}$. Operating a TSC at suction-face velocities below $0.02 \mathrm{~m} / \mathrm{s}$ results in lower instantaneous thermal efficiencies but higher air temperature rises.

Suction-face velocities of $0.04-0.05 \mathrm{~m} / \mathrm{s}$ are recommended for field installations to ensure wind heat loss and 'outflow' do not compromise the performance of the TSC (Gawlik and Kutscher, 2002; Kutscher et al., 2003). Outflow is where the heated air in the plenum exits through a section of the TSC absorber, thus losing the heat generated. Gunnewiek et al. (2002) identified that if the site wind speed reached $5 \mathrm{~m} / \mathrm{s}$, which would not be a typical wind speed for built-up sites in the UK, outflow would be prevented if the TSC were operating with suction-face velocities of

- $0.0125 \mathrm{~m} / \mathrm{s}$ under typical operating conditions

- $0.017 \mathrm{~m} / \mathrm{s}$ for long buildings facing into the wind

- $0.026 \mathrm{~m} / \mathrm{s}$ for cubical buildings with the collector facing the wind

- $0.039 \mathrm{~m} / \mathrm{s}$ for cubical buildings with the wind incident on the collector at $45^{\circ}$.

\section{Types of TSCs}

\subsection{Basic construction types}

TSCs come in three basic construction types - stand-alone, on a south-facing wall and rooftop-mounted. A stand-alone TSC is one where both the perforated absorber and the non-perforated sheets (see Figure 1) are exposed to the ambient environment and the TSC is supported independently of the building. This type of TSC is used for commercial drying applications (Leon and Kumar, 2007). 


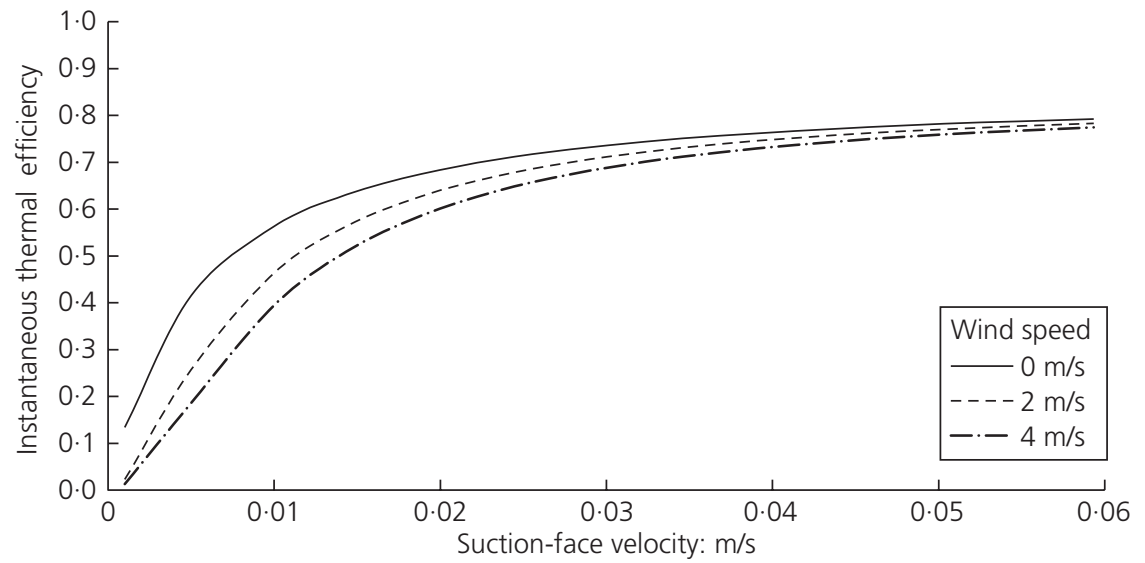

Figure 3. Instantaneous thermal efficiency against flow rate for three wind velocities (based on the assumptions in solar air heating project model (SAHPM) (Carpenter and Meloche, 2002) and using an absorptivity of 0.9)

Figure 4 shows a south-facing wall type of TSC, also known as an envelope-mounted TSC (Kozubal et al., 2008). In this construction type, the perforated absorber is fixed to the building façade of either a new or existing building. As the TSC is incorporated onto the existing façade, the additional components of the TSC are a single metal sheet (the perforated absorber) and the spacer system. In new-build applications, the same construction team can install both the building cladding system and the TSC.

The rooftop-mounted TSC (CEI, 2010a) sits on the roof of the building and can be used when there is no suitable south-facing wall area. This construction type has the potential to achieve higher energy yields than the south wall type due to the greater freedom to optimise the tilt, orientation and coating of the absorber (Kozubal et al., 2008).

\subsection{Photovoltaic TSCS}

Similar to other solar thermal systems, TSCs can also be combined with photovoltaic (PV) modules to create a hybrid

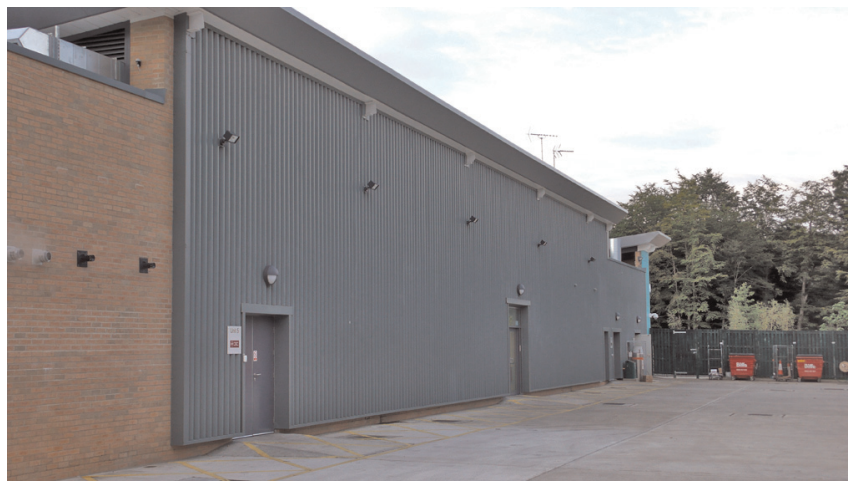

Figure 4. Commercial TSCs installed on the south wall of Beaconsfield service station (UK), where the TSC preheats ventilation air for the food court photovoltaic/solar thermal panel (PV/T) (Hollick, 2000a) that is, a PV/TSC. The aim of creating a hybrid PV/TSC system is to develop a device that can simultaneously convert solar radiation into economical heat and electricity when available collector area is at a premium (Charalambous et al., 2007), or simply to improve the economic performance of the PV system by cooling the PV cells (Naveed et al., 2006). There are two broad types of PV/TSC

- bonded type - PV cells/modules are bonded directly to the absorber (Delisle, 2008; Hollick, 1998)

- fixed type - PV modules are fixed to the absorber (CEI, 2010b; Naveed et al., 2006).

The bonding of PV cells directly onto the TSC perforated sheet has been researched by Hollick (1998) and Delisle (2008). They have been able to verify that the PV/TSC was able to lower the temperature of the PV cells, but the PV cells also resulted in a reduction in the thermal efficiency when compared with a standard TSC. The effect was attributed in part to the reduced absorptivity of the PV cells compared with the absorber. When bonding PV cells to a corrugated absorber, an important consideration is the location of the PV cells on the corrugations. When investigating the effect of two potential PV cell configurations (bonding just on the ridge or across the whole sheet), Delisle (2008) was able to conclude that there would be shading of the PV cells if bonded over the whole surface of the sheet. Thus, careful design of the PV cell configuration would be required. Currently, there is no commercial PV/TSC of the bonded type; this is thought to be primarily due to the difficulty in manufacturing suitable PV cells that can be economically bonded to the absorber.

The fixed-type PV/TSC, where conventional PV modules are fixed to the absorber, has been commercialised in both the 
south-facing wall form and modular form (CEI, 2010b; Hollick and Barnes, 2007). In one study, the forced ventilation of polycrystalline silicone PV modules using a TSC system was able to reduce the operating temperature of the $\mathrm{PV}$ modules by $3-9^{\circ} \mathrm{C}$. This cooling of the PV modules resulted in a reduction in simple economic payback time from 23 years (PV without TSC) to 15 years (PV/TSC) (Naveed et al., 2006).

\section{TSC systems}

\subsection{System types}

The most common application of a TSC is for preheating ventilation air, where the ventilation air supply is heated as it passes through the TSC perforated sheet. The heated air is then generally heated further as it passes through the building's HVAC system to reach the desired delivery temperature. In summer, when there may be no requirement to heat the ventilation air supply, TSC systems have a means of bypassing the absorber (Figure 1). Guidelines for the design of TSCs for ventilation preheating have been outlined previously (Brunger et al., 1999; Hollick, 2000b; Kutscher, 1996). A number of alternative system types have been explored, with various degrees of success.

(a) Cooling ventilation air (Hollick, 2007): at night, the temperature of the TSC absorber will be lower than the ambient air temperature due to radiant heat losses to the sky, thus enabling the TSC absorber to cool ambient air at night (Summers, 1995).

(b) Preheating water for a district heating network: TSCheated air is passed over an air-to-water heat exchanger (Frank et al., 2006).

(c) Hot water preheating (e.g. the correctional facility at Inuvik and the WIWOG Wohnbaugesellschaft, Germany (CEI, 2009a)

(d) Desiccant regeneration for cooling applications (Pesaran and Wipke, 1992).

(e) Diurnal cycle energy storage (e.g. at St Lawrence College, excess heated air is ducted through a hypocaust energy storage radiant flooring system (CEI, 2009a)).

$(f)$ Drying of agricultural products (e.g. chicken manure, cocoa and tea) (Leon and Kumar, 2007).

\subsection{Integrated performance of systems}

The predicted integrated environmental and economic performance of TSCs is primarily determined using either RETScreen ${ }^{\circledR}$ V3.1 solar air heating project model (SAHPM) (CEI, 2009b) or, in the UK, the simplified building energy model (SBEM) 2010 (version 4.0.a onwards) for Building Regulations Part L compliance (Hall, 2010).

RETScreen SAHPM is a free secure Microsoft Office Excel spreadsheet application designed to model preheating of industrial, commercial, residential ventilation air and for preheating process air. It uses Nasa (National Aeronautics and Space Administration) surface meteorology and solar energy weather data to calculate energy savings on a monthly average timestep using an efficiency equation similar to Equation 6, which takes into account the dominant variables of absorptivity, airflow rate and wind speed. The energy saving calculated is the sum of the active absorber solar gain and wall heat recapture (heat loss through the wall is recaptured into the air stream). SAHPM has been validated against $\mathrm{SWift}{ }^{\mathrm{TM}}$, which is a free dynamic simulation model for TSCs (Carpenter and Meloche, 2002; Carpenter et al., 1999). The two models showed good agreement in all the available TSC system types. While SAHPM can be used in the UK to model the performance of TSCs, SWift cannot be used as the software only includes North American weather files.

A comparison of the US National Renewable Energy Laboratory (NREL) TRNSYS TSC model with SAHPM found that the NREL model predicted $14 \%$ less delivered energy than SAHPM. The rationale was that the SAHPM is 'based on product offerings no longer available' (Kozubal et al., 2008: p. 4), which is likely to be referring to the observation that some manufacturers are using more extreme profiles than those originally studied for SAHPM and using slits rather than circular holes (Kutscher et al., 2003).

A TSC energy yield model is included in the UK Part L compliance SBEM (Hall, 2010). This model uses efficiency algorithms researched in the IEA solar heating and cooling programme task 14 (Brunger et al., 1999) and can model ventilation air preheating for most building types. TSC energy yield models are, however, not currently included in many of the building energy dynamic simulation software packages. Crawley et al. (2008) reviewed the capability of whole-building energy modelling software in 2008 and found that TSCs were only included in the EnergyPlus simulation engine (EnergyPlus, 2009) and the research tool TRNSYS (Langensiepen and Morhenne, 2010; Summers, 1995).

Table 2 compiles the principal findings of detailed performance investigations on existing TSC installations or models of potential TSC installations. Internationally, TSCs appear to be able to generate economic payback periods (i.e. the number of years required to pay back capital costs) of around 2-10 years (CEI, 2009a) depending upon the application, with less than 1 year needed to pay back their embodied greenhouse gas emissions (IEA, 2000).

UK-based integrated performance investigations are providing evidence to suggest that the performance of TSCs experienced in the USA and Canada over the past 20 years could be replicated in the UK. In 2007, a post-occupancy evaluation (POE) was undertaken to determine the actual first-year integrated performance of a TSC installation in County Durham (Pearson and Anderson, 2007). The POE found that the TSCs delivered 


\begin{tabular}{|c|c|c|}
\hline Study & Location & TSC system type \\
\hline $\begin{array}{l}\text { Christensen } \\
\text { et al. (1990) }\end{array}$ & $\begin{array}{l}\text { USA: Denver, } \\
\text { Madison, } \\
\text { Miami }\end{array}$ & $\begin{array}{l}\text { Retrofit envelope-mounted } \\
\text { TSC for ventilation air preheat }\end{array}$ \\
\hline
\end{tabular}

Principal findings

Pesaran and USA Desiccant cooling systems Wipke (1992)

\section{regenerated with a TSC}

$\begin{array}{lll}\begin{array}{l}\text { Summers } \\ \text { (1995) }\end{array} & \text { USA: } & \text { South wall TSC for ventilation } \\ & \text { Bismarck, } & \text { and air preheating } \\ & \text { Buffalo, } & \\ & \text { Denver, } & \\ & \text { Madison, } & \\ & \text { Washington } & \end{array}$

Brown (2003) USA: Various South wall TSC for ventilation Air Force bases air preheating
- TSCs are nearly cost competitive with natural gas heating

- The absorber area is much larger than alternative solar thermal systems

- TSCs installed on new buildings have a lower capital cost than TSCS retrofitted to existing buildings

- Energy performance of TSC system sensitive to length of heating season

n TSCs could not use the heat recovered by the sensible heat exchanger in the desiccant cooling system

- TSCs required $64 \%$ more absorber area than an equivalent glazed absorber based system

- Relative to glazed absorber based systems, TSCs are cost-effective

- Natural gas based systems are more cost-effective than TSC based systems

- Emissivity plays an important role when the TSC system is required to generate high output temperatures (greater than $50^{\circ} \mathrm{C}$ )

- Simple economic payback of around 10 years

- The TSC vertical tilt required for winter operation is not ideal for summer desiccant regeneration

- At night, the absorber's temperature can be lower than the ambient air temperature due to radiation losses to the sky

n Automatically opening the bypass damper at night leads to increased energy performance, except when the wall is poorly insulated

n The amount of time that the ambient temperature is below the summer bypass set temperature is a significant climate variable

- Additional fan power is less than $2 \%$ of energy saved

- Significant energy savings can be achieved in industrial buildings if high indoor temperatures are required and there is a high fresh air requirement

- Absorptivity and absorber area are important variables in energy savings

- TSCs are only cost competitive when compared with electric heating systems

- Simple economic payback between 4 and 14 years

- Internal rate of return between 6 and 30\%

n TSCs were economically beneficial for all of the Air Force bases investigated

- Fuel cost, capital cost and seasonal efficiency variables are the most import determinants of economic performance

Table 2. Principal findings from integrated building energy and environmental performance investigations 


\begin{tabular}{|c|c|c|c|}
\hline Study & Location & TSC system type & Principal findings \\
\hline Maurer (2004) & $\begin{array}{l}\text { USA: North } \\
\text { Carolina }\end{array}$ & South wall ventilation heating & $\begin{array}{l}\text { Results suggest that the presence of the collector can } \\
\text { increase the temperature of the building fabric in the } \\
\text { summer (more research is required) } \\
\text { TSCs are economical in North Carolina even though it } \\
\text { has a short heating season } \\
\text { Suggest separating the TSC mode in TRNSYS from the } \\
\text { whole building model }\end{array}$ \\
\hline $\begin{array}{l}\text { Naveed et al. } \\
\text { (2006) }\end{array}$ & $\begin{array}{l}\text { South Korea: } \\
\text { Daejeon }\end{array}$ & $\begin{array}{l}\text { TSC/PV (modular type) } 3 \mathrm{~kW} \\
\text { PV modules fixed in a } 50 \mathrm{~m}^{2} \\
\text { TSC }\end{array}$ & $\begin{array}{l}\text { TSCs reduced the temperature of the PV modules by } \\
3-9^{\circ} \mathrm{C} \\
\text { Requires three less } 75 \mathrm{~W} \text { modules than a system without } \\
\text { the TSC } \\
\text { PV/TSC requires } 50 \mathrm{~m}^{2} \text { whereas a PV and TSC would } \\
\text { require } 70 \mathrm{~m}^{2} \text { to generate the same output } \\
\text { Simple economic payback for the PV/TSC system reduced } \\
\text { from } 23 \text { to } 15 \text { years (given } 50 \% \text { government subsidy for } \\
\text { the PV modules) }\end{array}$ \\
\hline Ashley (2007) & $\begin{array}{l}\text { USA: New } \\
\text { York }\end{array}$ & $\begin{array}{l}\text { South wall TSC for high-rise } \\
\text { residential ventilation } \\
\text { preheating }\end{array}$ & $\begin{array}{l}\text { Optimal control strategy would allow for varying set } \\
\text { temperatures throughout the year } \\
\text { TSCs perform optimally at vertical tilts } \\
\text { Substantial wall recapture is possible in poorly insulated } \\
\text { buildings }\end{array}$ \\
\hline $\begin{array}{l}\text { Battle } \\
\text { McCarthy } \\
(2007)\end{array}$ & UK & $\begin{array}{l}\text { Envelope-mounted TSC for } \\
\text { ventilation preheating }\end{array}$ & $\begin{array}{l}\text { TSCs can contribute } 10-20 \% \text { of overall energy demand } \\
\text { of low-energy distribution centres } \\
\text { TSCs can make significant contributions to heated or } \\
\text { poorly managed low-rise buildings } \\
\text { In single-storey industrial buildings that only require frost } \\
\text { protection, TSCs cannot be used as a substitute for frost } \\
\text { protection and are unlikely to make significant energy } \\
\text { savings (due to the low demand for heated ventilation } \\
\text { air) }\end{array}$ \\
\hline $\begin{array}{l}\text { Kozubal et al. } \\
\text { (2008) }\end{array}$ & USA & $\begin{array}{l}\text { Rooftop-mounted modular } \\
\text { and south wall TSCs for } \\
\text { ventilation preheating }\end{array}$ & $\begin{array}{l}\text { Selective coatings (high absorptivity and low emissivity) } \\
\text { can increase energy savings made by TSCs } \\
\text { Higher absorptivity coating can be used for modular } \\
\text { designs because they are not within the view of people } \\
\text { A modular design enables optimisation of the absorber's } \\
\text { tilt } \\
\text { Modular absorbers have a } 28-37 \% \text { higher capital cost } \\
\text { compared with south wall designs } \\
\text { South wall absorbers can achieve } 10 \% \text { or greater internal } \\
\text { rates of return in DOE climate zones } 4 \mathrm{~A}-8\end{array}$ \\
\hline DSAE (2008) & UK & $\begin{array}{l}\text { Envelope-mounted TSC for } \\
\text { ventilation preheating }\end{array}$ & $\begin{array}{l}\text { To provide } 10 \% \text { of the building energy demand from } \\
\text { renewable energy would require } 595 \mathrm{~m}^{2} \text { of TSC absorber } \\
\text { and costs significantly less than other potential renewable } \\
\text { energy alternatives }\end{array}$ \\
\hline
\end{tabular}


$21 \%$ of the total heating demand of the building in the first full year of operation (2006-2007). A comparison of a range of renewable energy technologies for use on a building in the UK indicated that the TSC option could meet a $10 \%$ renewable energy planning policy requirement at a capital cost significantly lower than the alternatives (DSAE, 2008). Finally, a study of typical and low energy distribution centres reported that TSCs can make a 'significant contribution' to the operational energy demand of these types of buildings (Battle McCarthy, 2007: p. 9).

\section{Avoiding known international design problems}

There is considerable international experience of installing TSCs and, while the vast majority of these systems appear to be installed without issue, there are a few installations that have been the subject of POEs that aim to mitigate some form of design problem. The following design lessons can be derived from these international POEs.

(a) Warehouses with large doors that are open for a significant duration of time may lose the benefit of heat generated by TSCs (Deru et al., 2005).

(b) Distributing TSC heat from high-level fabric ducts in large spaces can be ineffective because the heat tends to stay near the ceiling and is unable to heat the occupied space. To resolve this problem, some method of destratification is required (Brown, 2003; Deru et al., 2005; Maurer, 2004).

(c) Where heating of a building's ventilation air is generally not required all year round, a means of bypassing the TSC is required (Maurer, 2004).

(d) TSCs operating with low suction-face velocities (below $0.02 \mathrm{~m} / \mathrm{s}$ ) can result in low solar conversion efficiencies and are vulnerable to wind heat loss effects (Fleck et al., 2002; Kozubal et al., 2008; Kutscher et al., 2003; Maurer, 2004).

(e) Since TSCs are driven by a fan, occupant exposure to fan noise should be considered (e.g. the installation of silencers may be required) (Brown, 2003).

( $f$ ) TSCs that are not integrated with a building's fire alarm systems can be problematic as the rate of combustion can be increased if fresh heated ventilation air is delivered during a fire (Brown, 2003).

( $g$ ) The performance of a TSC can be reduced in buildings with an early-morning dominated heating demand since a large proportion of the heating demand is at a time when there is no solar radiation available (Pearson and Anderson, 2007).

(h) Maintenance personnel require training to understand TSC technology so that if issues arise they are able to solve them without having to resort to switching the system off (Maurer, 2004). (i) Air quality adjacent to the absorber needs to be considered. For example, a car park directly adjacent to a TSC could result in car exhaust fumes being brought into the building (Brown, 2003).

( $j$ ) TSCs operating without auxiliary heating of the output air (not preheating) should consider the thermal comfort implications of delivering cool ventilation air to the building space (Meier, 2000).

(k) Some TSCs are not accompanied by a standard controller unit; sites with multiple TSCs may therefore have multiple controller units, making facility management more difficult (Brown, 2003).

(l) If water coils are present in air handling units being served by the TSC, when the ambient temperature is below freezing the air handling units will not draw from the TSC to avoid coil freezing, even if the heat from the TSC can bring the temperature of the air above freezing (Kozubal et al., 2008).

If the system is designed for ventilation preheating and space heating, then the design must take into account the facts that

(a) the collector area may be oversized for times when only ventilation preheating is required, resulting in very low suction flow rates and thus very low efficiencies (Kozubal et al., 2008)

(b) as TSCs are once-through systems, the air temperature rise from ambient to the return temperature does not offset gas use. This must be accounted for when calculating energy savings (Kozubal et al., 2008).

By using the knowledge gained through the experiences of installing TSCs in the USA and Canada over the past 20 years, these potential design problems can easily be avoided in the UK.

\section{Strengths and limitations of TSCs}

7.1 Strengths

(a) Long life of the absorber ( $>40$ years depending upon the quality of the coating) (CA Group, 2009).

(b) High efficiencies (wind having a negligible impact on the performance if the system is well designed) (Kutscher et al., 2003).

(c) Potential for heat recovery as heated indoor air passes into the plenum through the existing cladding (Summers, 1995).

(d) Can be applied to any building that requires heated air or fresh ventilation (single-storey commercial, offices, multiresidential, agriculture, process heating, etc.) (Hollick, 2000b).

(e) As the TSC absorber is an additional component to the building envelope, TSCs can be incorporated onto new and existing buildings. 
( $f$ ) Good aesthetic qualities (generally indistinguishable from a conventional metal cladding sheet and a wide range of colours can provide high absorption performance) (Munari Probst and Roecker, 2007)

\subsection{Limitations}

(a) The large size of the collector can limit applications to the tilt and orientation defined by the building envelope (mitigated to a degree with modular designs).

(b) Generally not suitable for high temperature rise applications $\left(30^{\circ} \mathrm{C}\right.$ over ambient air temperature) (Leon and Kumar, 2007).

(c) The large size of the collector means that the absorber needs to fit in with the building's aesthetic (the colour desired for aesthetic characteristics may not always be the ideal colour for a solar absorber) (Munari Probst and Roecker, 2007).

\section{Conclusions}

TSCs have been used successfully in the USA and Canada to provide preheating of ventilation air for buildings and the evidence suggests that they can compete against other renewable technologies. The incorporation of a simplified TSC energy yield model into the simplified building energy model will enable building energy practitioners to assess the performance of TSCs for Building Regulations Part L compliance. However, there is still a need to widen the uptake of TSC energy yield models within dynamic building modelling software. This paper has highlighted some potential design pitfalls that can be avoided if practitioners are aware of them. Overall, TSC technology appears to be a promising means of providing economically competitive renewable energy to a wide range of buildings in the UK.

\section{Acknowledgements}

The authors are grateful to the Engineering and Physical Sciences Research Council (EPSRC) for its support of the University of Surrey/Brunel University engineering doctorate programme in environmental technology, of which this study is part, and the Steel Construction Institute for continued support of this research. Thanks also go to CA Group Ltd for assistance.

\section{REFERENCES}

Ashley DR (2007) Reducing Ventilation Energy Demand in Multifamily High Rise Buildings through Preconditioning. Two Modelling Studies. Cornell University, Ithaca, NY. ASHRAE (American Society of Heating, Refrigerating and Air-Conditioning Engineers, Inc.) (2010) ANSI/ASHRAE standard 93-2010: Methods of testing to determine the thermal performance of solar collectors. Ashrae, Atlanta, GA. Battle McCarthy (2007) The SolarWall. Battle McCarthy, London, study carried out for CA Group.

Brewster A (2010) Using the sun's energy. Building Engineer 85(6).
Brown DS (2003) An Evaluation of Solar Air Heating at United States Air Force Installations. Department of the Air Force Air University, Air Force Institute of Technology, Ohio.

Brunger AP, Kutscher CF, Kokko J et al. (1999) Low Cost, High Performance Solar Air-heating Systems Using Perforated Absorbers. International Energy Agency, Paris.

CA Group (2009) The SolarWall ${ }^{\mathbb{R}}$ Perforated Transpired Solar Collector ( $p$ TSC). See http://www.cagroupltd.co.uk/ for further details (accessed 06/06/2011).

CA Group (2010) CA Building Products: Case Studies. See http://www.cagroupltd.co.uk/ for further details (accessed 06/06/2011).

Carpenter S and Meloche N (2002) The Retscreen model for simulating the performance of solar air heating systems. Proceedings eSim, the Canadian Conference on Building Energy Simulation, Montreal, Canada, 11-13 September, Session 1-3.

Carpenter S, Daniels S, Kemp S, Kokko J and Van Decker G (1999) New Tools for Assessing the Performance of Solar Ventilation Air Heating Systems. Solar Energy Society of Canada Inc., Ottawa.

CEI (Conserval Engineering Inc.) (2009a) Case Histories. See http://solarwall.com/en for further details (accessed 06/06/ 2011).

CEI (2009b) SolarWall by Conserval Engineering Inc. CEI, Toronto.

CEI (2010a) SolarDuct Modular Rooftop Air Heating System. CEI, Toronto.

CEI (2010b) SolarWall Photovoltaic/Solar Thermal (SolarWall $P V / T)$. See http://solarwall.com/en/products/solarwallpvt.php for further details (accessed 06/06/2011).

Charalambous PG, Maidment GG, Kalogirou SA and Yiakoumetti K (2007) Photovoltaic thermal (PV/T) collectors: a review. Applied Thermal Engineering 27(27): 275-286.

Christensen C, Hancock E, Barker G and Kutscher C (1990) Cost and performance predictions for advanced active solar concepts. Proceedings of Solar 90 The National Solar Energy Conference, Austin, TX. American Solar Energy Society, Inc., Austin, Texas, 275-280.

Corus Colors (2010) Colorcoat Prisma technical details. See www.colorcoatprisma.com for further details (accessed 06/ 06/2011).

Crawley DB, Hand JW, Kummert M and Griffith BT (2008) Contrasting the capabilities of building energy performance simulation programs. Building and Environment 43: 661-673.

Delisle V (2008) Analytical and Experimental Study of a PV/ Thermal Transpired Solar Collector. University of Waterloo, Ontario.

Deru M, Torcellini P and Pless P (2005) Energy Design and Performance Analysis of the Big Horn Improvement Center. National Renewable Energy Laboratory, Golden, CO. 
DSAE (DSA Engineering) (2008) Sustainability and Renewable Energy Plan (Buckingway Road Swavesey, South Cambridgeshire). DSAE, London.

Duffie JA and Beckman WA (2006) Solar Engineering of Thermal Processes. Wiley, Hoboken, NJ.

Ekins P and Lees E (2008) The impact of EU policies on energy use in and the evolution of the UK built environment. Energy Policy 36: 4580-4583.

EnergyPlus (2009) EnergyPlus Engineering Reference: The Reference to EnergyPlus Calculations. See http:// apps1.eere.energy.gov/buildings/energyplus/ documentation.cfm for further details (accessed 15/03/2011).

EU (European Union) (2010) Directive 2010/31/EU of the European Parliament and of the Council of 19th May 2010 on the energy performance of buildings (recast). Official Journal of the European Communities L 153/13.

Fleck BA, Meier RM and Matovic MD (2002) A field study of the wind effects on the performance of an unglazed transpired solar collector. Solar Energy 73(3): 209-216.

Frank E, Budig C and Vajen K (2006) Experimental and theoretical investigation of unglazed transpired air collectors in a multicomponent solar thermal system. Proceedings of Eurosun 2006, Glasgow, 27-29 June.

Gawlik KM and Kutscher CF (2002) Wind heat loss from corrugated, transpired solar collectors. Journal of Solar Energy Engineering 124: 256-261.

Gunnewiek LH, Hollands KGT and Brundrett E (2002) Effect of wind on flow distribution in unglazed transpired-plate collectors. Solar Energy 72: 317-325.

Hall R (2010) Transpired solar collectors now in SBEM. New Steel Construction 18: 30-33.

Hollick J (2000a) Hybrid photovoltaic/heating system. In Solar Air Systems: A Design Handbook (Morck O and Hastings R (eds)). James \& James, London, Ch. IV, pp. 128-130.

Hollick J (2000b) Perforated unglazed collectors. In Solar Air Systems: A Design Handbook (Morck $\mathrm{O}$ and Hastings $\mathrm{R}$ (eds)). James \& James, London, Ch. IV, pp. 150-157.

Hollick J and Barnes B (2007) PV Thermal Systems Capturing the Untapped Energy. See solarwall.com for further details (accessed 06/06/2011).

Hollick JC (1994) Unglazed solar wall air heaters. Renewable Energy 5: 415-421.

Hollick JC (1998) Solar cogeneration panels. Renewable Energy 15: 195-200.

Hollick JC (2007) Method and Apparatus for Cooling Ventilation Air for a Building. US Patent application 11/436,432.

IEA (2000) Solar Air Systems: A Design Handbook. James \& James, London.

Kalogirou SA (2004) Solar thermal collectors and applications. Progress in Energy and Combustion Science 30: 231-295.

Kozubal E, Deru M, Slayzak S et al. (2008) Evaluating the performance and economics of transpired solar collectors for commercial applications. Proceedings of 2008 ACEEE Summer Study on Energy Efficiency in Buildings, Pacific Grove, $C A$. Available at: http://www.eceee.org/ conference_proceedings/ACEEE_buildings/2008/Panel_3/ 3_107/ (accessed 08/07/2011).

Kutscher CF (1996) Transpired solar collector systems: a major advance in solar heating. Proceedings of the 19th World Energy Engineering Congress, Atlanta, GA, 6-8 November.

Kutscher CF, Christensen C and Barker G (1991) Unglazed transpired solar collectors: an analytic model and test results. Proceedings of the Biennial Congress of the International Solar Energy Society, Denver, Colorado, USA, 19-23 August. Elsevier, New York, 2, Part 1, 1245-1250.

Kutscher CF, Christensen CB and Barker GM (1993) Unglazed transpired solar collectors: heat loss theory. Journal of Solar Energy Engineering 115: 182-188.

Kutscher CF, Christensen C and Gawlik K (2003) Letter to the editor. Solar Energy 74: 353-354.

Langensiepen B and Morhenne J (2010) Type 302: Solar Air Heater Version 14.09.07. Büro für umweltverträgliche Energiesysteme, Munich.

Leon MA and Kumar S (2007) Mathematical modeling and thermal performance analysis of unglazed transpired solar collectors. Solar Energy 81: 62-75.

Maurer CC (2004) Field Study and Modeling of an Unglazed Transpired Solar Collector System. Mechanical and Aerospace Engineering, North Carolina State University, Raleigh, NC.

Meier RM (2000) Wind Effects on the Performance of a SolarWall ${ }^{\mathbb{R}}$ Collector: An Experimental Study on a SolarWall ${ }^{\mathrm{B}}$ at the Canadian Coast Guard Base in Prescott, Ontario. Royal Military College of Canada, Ontario, Canada.

Munari Probst M and Roecker C (2007) Towards an improved architectural quality of building integrated solar thermal systems (BIST). Solar Energy 81: 1104-1116.

Naveed AT, Kang EC and Lee EJ (2006) Effect of unglazed transpired collector on the performance of a polycrystalline silicon photovoltaic module. Journal of Solar Energy Engineering 128: 349-353.

Pearson C and Anderson N (2007) SolarWall monitoring CA Roll Mill. BSRIA Limited, Bracknell.

Pérez-Lombard L, Ortiz J and Pout C (2008) A review on buildings energy consumption information. Energy and Buildings 40: 394-398.

Pesaran AA and Wipke K (1992) Desiccant cooling using unglazed transpired solar collectors. Proceedings of the 1992 American Solar Energy Society Annual Conference, Cocoa Beach, FL. American Solar Energy Society, Cocoa Beach, Florida, USA.

Summers DN (1995) Thermal Simulation and Economic Assessment of Unglazed Transpired Collector Systems. Mechanical Engineering. University of Wisconsin-Madison, Madison, WI. 